\title{
Pan-Africanism and the Language Question: Re-reading African Cultural and Intellectual History
}

Kenneth Inyani Simala

\section{Introduction}

This paper examines the role of intellectuals in the development of Pan-Africanist linguistic nationalism. The specific aim of the paper is to analyse elite ideas about African linguistic nationalism and their role in African society from the perspective of the sociology of knowledge, a stance which understands ideas in terms of the social, cultural and civilisational milieu that produces and consumes them.

The focus of the paper is dictated by the fact that little, if anything, has been written on linguistic nationalism as a factor of Pan-Africanist ideology. This is in contrast with the abundance of literature on the political and economic aspects of the movement. Political theorists on Africa have had a lot to say about the 'language of Pan-Africanism' but very little to say about 'Linguistic PanAfricanism'. It is therefore argued in this paper that the structure of nationalism consists of two equally powerful components: traditional data (such as race, language, literature, tradition, and territoriality), and egalitarian ideology (such as freedom, equality and fraternity). Pan-Africanism was a type of nationalism that fused traditional culture and modern ideology to generate the great social power that it was. Thus, Pan-Africanist linguistic nationalism deserves special attention because not much has been written on this aspect of cultural nationalism, and yet cultural nationalism was part of the social struggle against colonialism and imperialism. Further, among the intellectual leaders of Africa, none have attracted less attention than the language reformers. 


\section{Intellectualising Pan-Africanism}

There is no agreement on the meaning, character and periodization of Pan-Africanism. Opinions on its meaning, aspirations, and nature will continue depending on whether we assume the phenomenon came into being in the eighteenth, nineteenth, or twentieth centuries. And, it is perhaps important to note that definitions Africans advanced during the 1960s often differed from those put forth by members of the African Diaspora.

Rayford W. Logan, an African-American historian, defined Pan-Africanism as 'self-government' or independence by African nations south of the Sahara. Chief Anthony Emahoro, a Nigerian politician, argued that it included the economic, social, and cultural generation or development of Africa; the promotion of African unity and of African influence in world affairs. Alioun Diop felt that PanAfricanism was more or less synonymous with the concepts of the 'African Personality' or 'Negritude'. Vincent Bakpetu Thomson and John Hatch viewed Pan-Africanism as the same thing as African unity (1967:7). Robert G. Weisbord, an African West Indian historian, believed that the phenomenon was a 'racial movement'. George Shepperson used Pan-Africanism when referring to the twentieth century movement and pan-Africanism to describe 'a moral sentiment of international kinship and numerous short-lived movements with a predominant cultural element'.

Whoever first expressed Pan-African sentiments may never be known. Consequently, it is futile to try to attribute the phenomenon to any one individual or trace its inception to a particular year. PanAfricanism became popular after the first Pan-African Congress that was held in 1900 in London and initiated by the African-West Indian barrister Henry Sylivester Williams. Before that, PanAfricanist feeling first became articulated in the New World during the century starting from the declaration of American independence in 1776. It represented a reaction against the anti-African racism that marked the campaign for the abolition of the Atlantic Slave Trade. It also found expression as well in resistance to European intrusion in Africa (Esedebe, 170). According to Wodajo (1964:166), the seeds of Pan-Africanism were implanted in Africa the moment the first alien coloniser set foot on her soil. In Africa, Pan-Africanism amounted to a rejection of foreign domination. 
Pan-Africanism is therefore a political and cultural phenomenon that in the early stage regarded Africa and persons of African descent as a unit. It aimed at the regeneration of Africa and the promotion of a feeling of solidarity among the people of the African world. PanAfricanism was equated to Black African nationalism, which was itself viewed as a spiritualistic and community-oriented (socialist) ideology (Mudimbe, 1983:144). Thus, Pan-Africanism emerged as a body of ideas clearly structured and influential in the thinking and the behaviour of Africans wherever they were. As the passion for the African nation, Pan-Africanism glorified the African past and inculcated pride in African values.

The preoccupation of Pan-Africanism with Africanness, that is, African consciousness, or the rediscovery of African values, and the recognition of Africa as the black matrix, was applied with great boldness to a whole continent. It was the intellectual bond that united Africa, and best interpreted its deepest soul. Pan-Africanists had a deep bond to their own culture, and they had a legitimate interest in maintaining this bond. They argued that access to a societal culture was essential for individual freedom. According to Mudimbe (1983:145). Pan-Africanist ideology was akin to trends of restoring traditional African philosophies. Like them, it was motivated by negation. Pan-Africanists opposed the negation of African societies imposed, first in the slave trade and then in colonization and balkanization. They delved more into social realism with a greater concern with African identity and national politics. As a matter of fact, no more fantastic idea has ever played a part in serious politics than that of Pan-Africanism.

The search for and assertion of Black and African identity cannot be fully appreciated unless in relation to European encounter with Africa. In fact, concepts like Negritude (cultural), Pan-Africanism (political) and Ethiopianism (religious), are all historically justifiable and have been employed as continental movements with the hope of making Africans more conscious of their community of interest and experience in the face of European colonialism in Africa (Okita 1992:180). They represented an ongoing intellectual search for black identity in the world and African responses to the European concept of "the Universal" as part of their broader rhetorical resistance to the complex colonial marginalization of the non-European Other. The 
most important contribution that intellectuals made was to create an original discourse out of their sense of the African-European encounter, an encounter marked by domination and resistance, by conflicts and attempts at harmonization, and by a white cultural monolith clashing with a dynamic of Africanity.

The involvement with the cultural factor in the whole matrix was to be expected. Culture is seen as infrastructural, and social, economic and political phenomena are often seen as symptoms of immanent culture (Yoshino 1992:10). Writing on intellectuals and cultural nationalism, Smith (1983:94) says:

Cultural nationalism has always constituted the creation and special zone of intellectuals. For they, above all, feel the need for a resolution of those crises of identity, which menace modern man, and which require of him a moral regeneration, a rediscovery and realisation of self, through a return to that which is unique to oneself, to one's special character and history, which cannot be severed from the individuality and unique history of one's own community.

African cultural nationalism was thus premised on two related, yet distinct, aspects: the aspects of 'identity' and 'solidarity'. The former was concerned with the exploration, formulation and emphasis of a nation's (racial) identity; the latter with the creation, maintenance and enhancement of solidarity among members of a nation (race). African intellectuals therefore occupied an important place in cultural nationalism. It was felt that African nationality and spirituality, the two most important elements that contributed so much to the glory of ancient Africa, had departed through western encounter and influence. Therefore, it was felt that under the impact of utilitarian Western civilization, Africa must reassert its vitality through the development of African culture. Intellectuals expressed and formulated ideas of cultural distinctiveness in one main approach: 'holistic' . They regarded Africa as a whole and assumed members of the 'African nation' shared a common 'soul'.

According to M'Bow (1992:12), cultural identity is the privileged medium through which the individual asserts himself/herself against another; it is the decisive lever for collective and individual liberation, for creation, progress and development. Culture gives us the justification for existence; it gives us the perspective necessary to rethink the meaning of the future: the relation between our 
means and our ends, man and technology, society and nature, the individual and the state; it also gives us the impetus to leap over today's obstacles and clear new paths to tomorrow. It is only if we go back to the very sources of culture, the living hearth of inspiration, continuity and renewal of each people, that we become starkly aware of the limitations of any development effort based solely on the principle of material growth, and more so when modeled after a unique economic example.

For scholars like Hans Kohn (1955:9), nationalism is basically a subjective 'state of mind'; for others such as A.D. Smith (1971; 1973) it is primarily an ideological movement. Also, nationalism can be a latent phenomenon expressed mainly as pride in the nation's history and way of life, or it may develop as a dynamic force demanding strenuous efforts and immense sacrifice on the part of the members of the nation. Whatever aspect of nationalism one refers to and whatever form nationalism may take, the common denominators of nationalism are the belief among a people that it comprises a distinct community with distinctive characteristics and the will to maintain and enhance that distinctiveness (Yoshino 1992:6).

African cultural nationalism began to develop in the late nineteenth century with many educated Africans falling back upon their indigenous culture in the wake of Western cultural penetration. That was the time when the glory, genius and vitality of Africa ended and its spiritual and cultural degeneration started with the influx of Europeans. Modern Africans then accelerated their cultural decay under colonialism.

Perhaps aware of the fact that it is only Africans who are capable of preserving and creating their culture - of making history, there was enhanced affirmation of the indigenous culture of Africa. The African thinkers' exploration and emphasis of African distinctiveness were explicit, autocritical and vigorous in expanding the philosophical dimensions of understanding the needs of the development of Black Africa. A series of Pan-Africanist meetings held was a clear testimony of the national awakening in Africa on the intellectual and political levels. The meetings were made possible by a multiplicity of reasons among which were the information media and means of communication introduced by modern civilization and the new ideas which infiltrated and stirred up the hitherto placid intellectual life 
of the conquered countries through that cultural contact with their conqueror; world awareness of the problems of economics and politics, the newly learned tactics of resistance and the rights of peoples.

The distinctiveness of African culture became a major focus among Pan-Africanists when Africannness/Africanity emerged emphasizing the civilizational past of Africans rather than the territorial and political nature of the continent. This was the message of the first Pan-African Congress held in 1900 in London. Eight years later, the important theme of 'indigenization' featured prominently during the Pan-African Congress of 1908. Four PanAfrican Congresses of 1919, 1921, 1923 and 1927 summoned by Du Bois, underscored the centrality of Africanity. The year 1929 marks the emergence of notable African intellectuals and scholars. From this time, racially and socially important critical writings appear. Nearly all publications by Africans show their engagement with colour and culture. The purpose of that commitment was to create a new discourse that would stand separately from and, sometimes, in opposition to the discursive systems inherited from metropolitan Europe. The late 1930s through the 1950s marked a period of international insecurity. For Pan-Africanists, the racial and social justice themes and the perennial problem of identity dominated. African intellectuals were also ideologically committed; hence a majority joined political parties. In the 1950s, Kwame Nkrumah's political credo was 'seek ye first the political kingdom and all else will be added unto you'. Later, the serious limitations to this seductive credo of the primacy of the political process as a panacea for achieving the total liberation, unity and development of the African continent became clear.

In 1962, the Congress of Africanists, the precursor to the Congress of African studies, was inaugurated at the University of Ghana, at Legon in Accra by President Kwame Nkrumah during the heady days of Ghana's newly won independence. The Congress was founded as a visible beacon of Africa's intellectual and cultural birth. During the International Congress of Africanists held in Senegal in 1968, it was generally agreed that the days of European patronage were over and had been replaced by individual African governments. Participants were then more concerned with changes necessary within Africa itself in order to enhance its contribution 
to world civilization. The battle about whether Africa had anything to contribute had been won and it was now the nature of its quality with which they were concerned (Nicol, 1979:6). In all the PanAfricanist meetings, almost all the discourses had as their essential point of reference the historical existence, organisation, and culture of African peoples.

Among the intellectuals who systematised the identity of the African community were historians and artists (like Nyerere, Neto, Senghor). All these were prominent in discovering and presenting the foundations in time of communal regeneration. They argued that it is by discovering the history of the continent that its members rediscover its authentic purpose. As Banerjea (1971:235) argues, the study of the history of one's own country furnishes the strongest incentive to the loftiest patriotism.

Breuilly (1982:338) summarises the historicist argument and concern with national distinctiveness, which centre on the discovery of the uniqueness of the ancestral culture and the emphasis of a shared history, as the only way to apprehend the spirit of a community. In Africa, politics was the engine that helped achieve other ends. Far from distracting attention from cultural affairs, politics served to distill thoughts and concentrate concern for the creation of a new African society. African leaders saw this new society as one retaining much of traditional African civilization, blended with imported ideas of a better society. Leaders sought for Africa an intellectual decolonization, to take its place alongside political independence. African universities had to train individuals who could help construct the new African society. Nkrumah saw Ghana and Africa moving into an age where socialism shaped societies and Africans joined in a union of states that embraced the entire continent. To achieve this objective, African universities would have to produce citizens whose thinking was consonant with these ideas, who were aware of Africa's destiny, as Pan-Africanist leaders then understood it. The universities that were inherited from the colonial administration, however, were ill adapted to their needs. They had been created in faithful replica of European models with rigid structures of degrees that emphasized Western institutions and values to the virtual exclusion of Africa, its history and way of life. African leaders sought an Africanised curriculum and a radically altered educational philosophy that 
stressed the history, culture and institutions, languages and arts of Africa in new African centred ways, in entire freedom from the propositions and presuppositions of the colonial epoch (Nkrumah, 1964). Nkrumah's 'African personality' concept argued an African presence of unique culture in the world determined to pursue African interests in the arena of international affairs. The idea signified a theoretical construct made of pan-African symbols.

From the foregoing, Pan-Africanism then is the general sophistication of the African cultural and intellectual tradition. Pan-Africanism is for some a concept or an idea, or historical and existential fact. It is a representation of Africanness: it refers to being African and to the acceptance of that Africanness in a world whose imaginative and scientific efforts are strongly cultural and racial. Indeed, on a broader scope, Pan-Africanism was linked to the fervent vitality that characterised the period of Reconstruction in North America, roughly from 1863 to 1930. The movement benefited from the movement toward Africa led by Marcus Garvey, the intellectual revolution spearheaded by Du Bois, the black cultural 'Golden Age' expressed in the Harlem Renaissance, as well as other black cultural movements. Thus, as a syncretic Africanity, an African consciousness, Pan-Africanist discourse principally is a black interest in and cultivation of African ancestrality. It uses reasoning, arguments, inferences, and analyses that have everything to do with Africa and African thought. Because the idea of Africa is its main focus, it is Afrocentric.

The Afrocentric idea became a rhetorical reaction against the tendency to treat the whole world civilization, history and development only from a western perspective. It suggests the need to reevaluate reality as well as the discursivity that engenders reality as it affects Africans. It rejects the 'us-versus-them' mentality embedded in the colonial and imperialistic ordering of Africa and things African. Pan-Africanism has emerged therefore, as a discursive challenge to the marginalization of Africannness, and to work toward African reconstruction. It is a challenge encompassing politics, economics, and culture, broadly conceived. African intellectuals strive to portray Africa and Africans as contributors to the history and culture of the world. This historical reconstruction then is impelled by a sense of African self-renewal and self-affirmation. 
The chief centres from which the intellectual life of Africa radiates and a vibrant Pan-Africanist critical frame of reference still exists, are African universities and learned societies. Among learned Pan-Africanist societies, first rank is taken by the Council for the Development of Social Science Research in Africa (CODESRIA), in the work of which African scholars take a large and increasing part. This organisation, founded through the initiative of African intellectuals, has given much encouragement to the development of African research, and its members included leaders in the intellectual life of Africa.

On the evidence of Olukoshi (2002:1); the Executive Secretary of CODESRIA:

When CODESRIA was founded in 1973, it was established on a host of ideals which could be summarized as entailing the search for a credible forum located in Africa to serve as a home - if not the home for the entire African social research community. As a home, it was consciously conceived and constructed to accommodate the disciplinary, methodological, linguistic, geographical, gender, or generational diversities that characterise the African social research community. But these diversities were equally anchored on a broadly shared commitment to Pan-Africanism, the promotion of multi-disciplinary interaction, academic vigour and integrity, the independence of African scholarship and the promotion of research deriving from and relevant to the African context. Also integral to this commitment was a concern to ensure that the African academy played a full role in the quest for improved human livelihood on the African continent.

\section{African intellectuals and knowledge production}

During the colonial era and before, Europeans had unceasingly assured Africans that their own culture was barbaric and dated, and that it was best to emulate the European as quickly as possible, to get on with the business of joining the modern world. Thus, Europeans introduced into Africa a system of education based entirely upon their own ideas and experience, a system which in the event served to impede the spontaneous development of indigenous African culture and to substitute in its place an artificial exotic growth. The 
systems of education were purely a product of a priori reasoning, without regard to the historic background of African culture, nor to the economic and social needs of Africans.

The systems of education were evidently apt to make African countries poor by stunting intellectual growth. Prior to the coming of colonialists, Africa enjoyed an era of intellectual languour; African intellectuals, aware that great things lie in the past, turned their eyes to the past for guidance. Then suddenly, this connection with the past was severed, and the African intellect was invaded by the conflicting notions and ideas of European literary culture, imparted in a superficial manner. Quite demonstrably, Europe began to treat Africa as the distant other from about the fifteenth century when Portugal and Spain sought new territories overseas. The Euro-African unequal encounters in the Americas intensified the process of 'othering' Africa. In particular, from the mid years of the nineteenth century onwards, certain factors led to a deepening and widespread belief that the 'primitive' was interchangeable with the Dark continent and with things African. It was held that the primitive was located outside the industrialized world and that there was a scientifically measurable human difference between nontechnological and more advanced consumer societies. Those factors, all of which were to impact upon the creative imagination about Africa, included the effects of Social Darwinism, anthropological findings and geographical explorations in Africa, the founding of European museums with special interest in primitive treasures, and the political expansions of Europe that culminated in the partition of Africa in 1884 (Kubayanda 1990:18).

In history lessons, pupils learned the names of the great European explorers who sailed in their magnificent ships all over the world. They learned the dates when different physical features in Africa were 'discovered' and who was the 'first man to see' them. This education taught them that civilization did not exist in Africa until the Africans were enlightened by the Europeans. They also learned the names of European geniuses who made great contributions to the advancement of their countries through the machines that they invented. This education taught them that Africa was underdeveloped because her people lacked intelligence and creativity. Pupils learned the names of all the great rulers of Europe and the dates when they 
reigned. They learned the dates when all the great wars were won. In English literature, for example, Shakespeare, Dickens and Hardy were studied. Africans were eager to learn European languages.

Prof. Hugh Trevor Roper's declaration in 1963 that 'at present there is no African history but only the history of the Europeans in Africa, and that all the rest is darkness and darkness is not a subject of history' is well known. Earlier on in 1928, the Chair of Colonial History at Oxford University, Reginald Copeland, said:

The main body of the Africans, the Negro peoples who remained in their tropical homeland between the Sahara and the Limpopo, had no history. They had stayed, for untold centuries, sunk in barbarism. Such, it might almost seem, had been nature's decree. So they remained stagnant, neither going forward nor going back. Nowhere in the world was human life so stagnant. The heart of Africa was scarcely beating (Boahen 1985: 804).

That the Black peoples of Africa have no history and have no meaningful place in the history of humanity was the fog of racial prejudice and ignorance which characterized European thinking since the nineteenth century about the continent's ahistoricity, typified by philosopher Hegel's opinion that the Black peoples of Africa formed no part of human history, and Richard Burton's view that it was 'egregious nonsense' to question the natural and inherent superiority of Europeans over Africans (Davidson 1984:13). The nineteenth century was indeed a crucial moment not only because it was the highest point of European colonial expansionism in Africa, but also because it saw the perpetration of several negative images of Africa. It fostered a variety of psychological, anthropological and sociological ideas misrepresenting Darwin's theory of evolution and delineating the black other as mentally and culturally inferior. Racist ideology and scientific or pseudo-scientific thought met and interconnected, providing an adequate set of concepts and discursive forms to represent people of colour as occupying the lowest rung of the cultural hierarchy. By the dawn of the twentieth century the idea of primitive Africa had become full-blown in Western discourse and institutions.

Africans had long been made to perceive themselves to be on the "periphery" in relation to the 'central' civilizations where the 'universal' norm was supposed to exist. The West constituted the 
reference point from which Africans borrowed models and against when they affirmed and reaffirmed their identity. For most Africans, Western educational experience was akin to acquiring the "universal civilization'. Schools in Africa were neither a place where African identity was nurtured nor a source of knowledge about the history of Africa. Education was to convince Africans that their motherland had no history and had no meaningful and dignified place in the history of humanity. The African was represented as "the lowest anthropoid" and therefore uncivilized, since civilization was often equated with the ability to read and write, profession of the Christian faith, proficiency in a European language, and cultivation of European ways of life. Unfamiliar African cultures and societies were treated with condescension and contempt.

The denial of the history and the identity of Africa was an important strategy used by Europeans to enslave and colonize Africans for, by portraying people as less than human, it was easier to treat them as work animals. No system could have been more successfully devised for the intellectual emasculation of a race than education. Instead of training the power of observation, developing reason and judgement through social and historical investigation, and using literary studies for the nourishment of the critical and constructive faculties, African education was made up mainly of learning by rote parts of an alien literature and half-understood summaries and abstracts. The passing of language examinations, which were the portal to official employment, was the end-all and be-all of this education. The energy of students and teachers was bent on language tests and their successful accomplishment was the sole criterion of educational methods.

The net result achieved was to exaggerate certain 'native' defects of the African intellect. But it was not only the mental constitution of the African people that suffered through this superficial method of education. The development of character itself has been affected, as the youth have not received, together with their intellectual discipline, the needful training of their moral nature; the education they received was disconnected from the ethical impulses native and natural to the African mind, and had not provided the youth of Africa with definite moral aims. It is paradoxical that the European system of education, introduced to liberate the African mind from the 
superstitions of a backward learning, has had the result of enslaving rather than setting free, of weakening rather than building up, the intellectual forces of Africa.

The present situation of African intellectual life clearly shows an unusual dissociation of the educated from the masses of the people. The educated world is of course everywhere in danger of losing its contact with the broader currents of human life and experience; but in Africa, where the learned class has been reared upon an alien culture, this detachment is especially noticeable. The intellectual leaders are not fully understood by their own people; in other words, those whose intellectual powers entitle them to leadership have received from their education little assistance toward making such leadership effective. It is perhaps correct to say that the actual influence of the educated Africans has often been overestimated. Their command of European languages like English, French, German and Portuguese enables them to make themselves heard in the world. But, on the other hand, their alien training prevents them from being always the effective interpreters of what the silent millions of the African masses feel.

That the Europeans harboured a sinister motive to destroy indigenous culture, and impede the development of national life in Africa is in no doubt. In the leading European countries, there has been an uninterrupted development of national culture, disturbed at times, retarded, warped by external factors, yet in the main a continuous growth. There has at least been no violent break in traditions. Nor has there even been a long period of decadence and stagnation. Their literature, science, philosophy and ethics are intimately connected with their past traditions, out of which they have been gradually developed. As concerns Africa, the European episteme, expressed through its scientific formulations and languages of conquest, has 'inscribed [racial] differences as fixed and finite categories' between 'superior' and 'inferior' beings (Gates, Jr. 1986:6).

The 'othering' of the 'primitive' African was challenged by African intellectuals through various activities. In them, there was a consciously stated resolve to reconsider the African past in order to impose a new meaning on the present and the future. In the whole of Africa, there was an orientation toward a new destiny: movement, change, progress, even in the names. There was a widespread 
inspiration to deconstruct the acquiescent, the static, the timehonoured notions of grandeur, and the colonial rhetorical traditions. It should be noted that during the late 1920s and throughout the 1930s, Africa represented a complex idea. At times, it was no more than emptiness or darkness, a negative consciousness fed by the colonial and imperial phenomena in African culture. European cultural hegemony held the European traditions in place and almost systematically undercut the African dynamic in societal life. It was during the same period that a definite group of intellectuals was emerging, and whose goal was to bear witness to the aspirations of their generation and to unify through artistic and intellectual contacts, a historically scattered and brutalized people. Theirs was supposed to be a vindication of the indigenous African culture that had been held in disrepute. During the 1920s and 1930s when African intellectuals were beginning to write in the context of their national realities, the European civilization was still generally defined in terms that excluded the contributions of Africans. A continuing marginalization of Africa was no longer altogether feasible because of the emergence of Africans of power and vision. The subject of 'civilization versus barbarism' was a major cultural and intellectual concern.

During the Second World War in Paris, a group of black students from French-speaking Africa and the West Indies led by Aimé Cesaire of Martinique and Leopold Sedar Senghor of Senegal formed a movement, which, among other tenets held a central one that there was a common cultural identity among all peoples of African descent which they called Negritude. This identity needed strong assertion for it to be properly recognised and for its contribution to world culture to be acknowledged. Negritude was necessary because colonial empires had assimilationist policies which encouraged the adoption of their cultures and the shedding of indigenous African cultures as a sign of the civilized person who could then take their place socially, intellectually and indeed legally in the society of the metropolitan countries and their overseas territories. Africans in the French and Portuguese spheres of culture had mastered European civilization and had in some cases substituted their African culture completely by them. They had become black French and Portuguese and were accepted in Paris and Lisbon as such. Nonetheless, these people had to rediscover their African culture and assert it against 
the pervasively assimilationist European culture. At the same time, they had the ability of being able to place their African culture in the context of Western and indeed world civilization with which they were also familiar.

These processes then for the educated African of rebellion against western culture, rediscovering African culture and re-aligning it with other cultures, were particularly significant for the birth of the concept of Negritude. Alioune Diop was an active member of this group of intellectuals and in 1947 the literary journal Presence Africaine was founded under his editorship. Explain the relationship of African culture to world culture, Diop, a prominent Egyptologist, consistently argued that black Africa constitutes one cultural unit, and that historically, black Africa became an active participant in the early Egyptian civilization. He even suggested that black civilization transcends boundaries, from the Atlantic to the Sahara (Nicol, 1979: 3-4). Diop had political power because he had access in a quiet but effective way to most of the African heads of Government. He and his colleagues at the multilingual Presence Africaine, felt the need to bring together men of intellect of African descent to form a cultural movement. As a result, the first Congress of Negro Writers and Artists was convened in Paris in 1956.

It was that whilst in the 1940s the Anglo-Saxon African was holding, with a strong political flavour, the Pan-African Congress in Manchester, England, attended by figures such as Du Bois, Jomo Kenyatta and Kwame Nkurumah, the French Africans were launching Negritude in Paris under Senghor, Jacques Rabemananjara (later Vice President, Madagascar) and Aimé Cesaire. Van Niekerk (1970) interprets Senghor's enterprise as a preoccupation with the sources of African civilization as well as a quest for a way of bringing Africa and its human sciences to the attention of an ignorant Europe.

The years directly after World War II were especially conducive to the revival of indigenous culture. Post-war nationalist movements preached political independence and economic modernization, but there was also the urge for a concurrent reaffirmation of Africa's own values as expressed in its arts, its literature, its philosophy, and its history. Political freedom would thrive best, it was said, when accompanied by a parallel autonomy of cultural expression. It would be expected that independence movements in Africa would 
be accompanied by an intensified interest in Africa's past. New nations sought legitimacy in a long-lived history. Shivji (2003:109) describes the period after the Second World War to the defeat of US imperialism in Vietnam in 1975 as the age of national liberation and revolution when 'Countries want Independence, Nations want Liberation and People want Revolution'. This was also the age of great intellectual and ideological ferment. Every revolution and liberation struggle had its theoreticians, its thinkers, its arsenal of articulated ideas, not just arsenal of weapons. In other words, masses had to be moved by ideas before they could move mountains.

In most African countries, socio-political developments were by all means favourable to the evolution of an intellectual leadership in direct touch and harmony with other social forces. There was a rising tide of a fervent nationalism that found expression in an aggressive scholarship. Such a development required more than political speeches, for it entailed a re-establishment of the Africans' humanity and their pride in Africa's past achievements and future goals. The process began in the critiques of European models of development and social change. African intellectuals argued that any effective economic and social development must be based upon a firm foundation of African cultural authenticity, distinctiveness and individuality. The modernization of Africa needs not be synonymous with its westernization. Africa's modernization, thus, is a cultural challenge encompassing the arts, music, dance, poetry, beliefs, values, traditional religious systems, law, custom and knowledge, plus any other capabilities and habits acquired by members of society.

African intellectuals devoted themselves to the renaissance and promotion of classical African culture. The work of a number of individuals broke new ground: the research of historians like B.A. Ogot (Kenya), Ki-Zerbo Joseph (Burkina Faso); Adu Boahen (Ghana); Ajayi (Nigeria); innovative and provocative writings of Cheikh Anta Diop (Senegal); musicians and musicologists like J.H. Nketia and Ephraim Amu (Ghana); dance scholars like A.M. Opoku (Ghana); literary artists like Chinua Achebe and Wole Soyinka (Nigeria), Ayi Kwei Armah, Isidore Okpewho, Amadou Hampate Ba, Boubou Hama, H. Mokhtar, Theophile Obengo, H. Djait, Efua Sutherland; Ngugi wa Thiong'o (Kenya); Taban Lo Liyongo (Sudan), among others, helped to give shape, direction, and purpose 
to a new way of looking at Africa. These were among African intellectuals who believed that African civilization still survived, and it still offered its people much that was satisfying and much that worked. They recognized this fact, and were concerned that too rapid and unreflective an adoption of foreign ways might lead to complications, unforeseen and dangerous. They did not wish to turn their backs on the West but they did warn that African needs and conditions should always be given first priority (July, 1983: 119).

The above scholars exemplify in their intellectual life the best results of the contact between Africa and the West. With their intelligence quickened and their mind enriched by Western learning, they remained true to their indigenous culture, which they studied from a new point of view. Research and teaching in African studies - history, languages, literature, culture, anthropology and sociology - were started at African universities. Particularly, in the new universities of the former British colonies, departments of history were quick to introduce courses on the African past while interdisciplinary institutes of African studies also appeared on a number of African campuses. Their activities were particularly noteworthy because they were closely related to ideas on education then being argued by African Heads of State. The most important contribution that African intellectuals made in these universities was to create an original academic discourse out of their sense of the African-European encounter. This distinct and legitimate way of looking at Africa and the world, was an instrument that would serve to prevent a complete neutralization of the African cultural voice. Theirs was an intellectual rescue and recognition of Africa, as well as a conscious agent working against the mismeasuring of Africanity by Eurocentric critical constructs.

Colonialists had invented numerous 'theories' about the inferiority of black races and their inability to create cultural values or appreciate the treasures of world civilization. African culture, according to them was 'low' and 'primitive', and educated Africans were taught to despise it. However, African intellectuals wrote to prove that Africa was the continent that was the cradle of civilization of art and religion. They argued that the history of human civilization was the history of African and African civilization. They saw their task as an effort at regaining that lost glory, an initiative that 
would enrich the culture and civilization of humanity. This would be realized through the solidarity and unity among Africans who had suffered bitter experiences imposed on them by the barbarism of imperialism and colonialism. As far as aims and objectives were concerned, colonialism in Africa was explained as aiming at economic exploitation of raw materials, manpower and markets; and cultural domination embracing religion, language, customs, behaviour and social patterns.

Cultural identity had to be accepted as a determining factor of worldwide importance. Apart from being accepted, this basic reality had to be fully and immediately accepted in its many forms and in all its complexity. The import of this reasoning was vividly captured by M'Bow (1992:12):

Cultural identity is one of those vaguely demarcated realities whose multiple incidences on the life of societies had remained long unknown but which at present forced itself on everyone's attention in no uncertain manner... In the last fifty years, during which many peoples were faced with the crucial problem of acceding to sovereignty, it was only natural that national identity be used as a stepping stone towards an essentially political objective.

The emergent wave of heroic struggle and noble rebirth which was sweeping across the continent demonstrated how imperialism had imposed its inhuman system so as to try to undermine the very foundations of Africa's ancient civilizations and to destroy African culture and national character. Great harm was done to Africa's peaceful development and culture by colonialism. African intellectuals were conscious of the indignities and humiliations suffered by their race. Racism during the pre-colonial period was no more than a social stigma. The radical and systematic use of racism for blatantly exploitative motives did not therefore exist in the pre-sixteenth century period. Adverse racial propaganda of the eighteenth and nineteenth centuries had by extension legitimised the low cultural standing of the black person. That was part of the colonial ideology that justified the economic exploitation of blacks by advancing racial and cultural theories.

The beginning of the twentieth century was a culmination point of years of historical gestation and development in black consciousness. African intellectuals adopted an affirmative strategy to rehabilitate 
the black past and reinstate the black person to a status of worth and dignity by elevating the strength and virtue of the race. The protest literature focused on the cultural aspect of the African life, and was aimed to counterbalance and neutralize the negative impact of the old ideology on the cultural status of the Africans. A massive movement of blacks from rural Africa to the cities and to Europe had taken place. The period also witnessed the participation in and heroic contribution to World War I (1914-1919) by Africans. The rallying cry before the end of the war was that of making the world safe for democracy and extending justice to all. From the 1960s, Africanization is no longer an identity quest shaped by the colour of the African cultural world in opposition to the Eurocentric 'othering' of Africa and things African; rather, from then on, it begins to take a more critical look at the structures and practices of power that had come to replace the European hegemonic codes in Africa.

African intellectuals exercised a great influence upon public opinion in favour of cultural reforms, which they made appear not only desirable but also necessary. The romantic view of African history and culture expounded by African intellectuals had a powerful influence in arousing the national spirit of Africa. Among the areas that were inspired by the Pan-African activities, which had Africa and the Afrocentric heritage as its common take-off ground, were African languages.

\section{Pan-Africanist Linguistic Nationalism}

One of the most difficult problems in national and cultural advancement of Africa is language. The language question has elicited a great deal of debate and attracted the attention of political leaders and national intellectuals in all African countries. The language question can be projected into the African historical context and be seen as part of African history.

Thus, the language question can best be understood as a development in response to European contact with, and colonization of, Africa. In that contact, linguistic domination and control, conflict, resistance, adaptation, assimilation, and other developments took place, thereby threatening the wholeness of African languages. The salient factor in the historical background out of which the language 
question arose can be identified as the experiences of subordination to what were perceived as culturally superior foreign languages - English, French, German, and Portuguese. Broadly speaking, invasion, settlement, enslavement, education, and evangelization characterized domination and control. Acculturative conflicts occurred naturally, when less powerful groups, the marginalized Africans, moved against the establishment of control models.

The phenomenon of cultural nationalism, of which language revivalism was a part, must be seen as a reaction to the psychology of colonialism as analysed by Franz Fanon, who describes two sets of images promulgated by the colonizer and often uncontested by the colonized: one involves the settler, who brings reason, enlightenment, order and progress; the other is of the native who lives in a bestial or childlike world of superstition, darkness, anarchy and backwardness. The rebellious reaction, albeit subtle, of individual Africans to colonial authorities who forbade African tongues was the genesis of African linguistic nationalism. The political position and fiat used to force Africans into adopting European languages add up to the circumstances that placed severe obstacles in the worth of healthy identity formation. Thus, African language politics during colonialism was characterized by widespread disaffection and alienation which found expression in a rising tide of cultural and linguistic nationalism (Simala, 2001:317-318).

Besides colonialism, there is also one other development which has been determinant in the rise of African linguistic nationalism. The coming of age of a new generation of Africans educated in Western systems of education, and who were radicalized by the gap between reality and practice. These were the driving force behind Pan-Africanism, an increasingly important origin of African nationalist and liberation movements. These intellectuals became a large, moderated well-defined and partly self-conscious group. Thus, according to one of them, Ki-Zerbo (1986:46):

The historical and contemporary dilemma in which African peoples find themselves reflects a crisis of consciousness, or rather a crisis of lack of consciousness - consciousness about what actually happened to us and the factors responsible for it, consciousness of the ultimate intentions of our 'partners' in various abortive programmes of development. To deal with the crisis of consciousness, we must first 
of all turn our full attention to "that most manifest and coherent of all cultural systems - language... Language is a creative force, a fundamental tool of civilization and development. The very concept of what it means to be "human" is invariably defined with reference to language. The essence of our humanity and of our uniqueness as a species is a function of our language.

If language is such a fundamental requirement of our capacity as humans, any disruption in language will inevitably subvert our capacity for human development. In other words, language does (help) create civilization, but it can also (help) destroy or undermine its development. Indeed, the human element of every civilization appears to be the language factor (Balde 1986).

Chinua Achebe argues that culture is not only a force of creativity, but also the utilization of human intelligence for social development. But culture cannot achieve its creative and utilitarian potential without the vehicle of language. Given that language is crucial to the creation of society, there is no way in which human society could exist without speech (Language 87:46). The most influential advocate of the use of African languages in African development programmes was Cheikh Anta Diop, who urged us:

.... to create our linguistic unity through the choice of an appropriate African tongue promoted to the influence of a modern cultural language. Linguistic unity dominates all national life. Without it, national cultural unity is but fragile and illusory.... European languages must not be considered diamonds displayed under a glass ball, dazzling us with their brilliance. Our attention must be fixed on their historical development. Creatively, we discover that similar paths are open to us (1978).

A similar view was held and expressed by Kofi Anyidoho (1992) who argued that a people denied the ability to name themselves, their own experiences, and in a language native to their very souls, their secret selves, is a people degraded to the state of shadows, shadows of other selves. It is a people in danger of annihilation. Language is not only the key to a people's identity; it is the strongroom in which the inherent soul of a people can be protected from 'the too rough fingers' of a predatory world.

Samir Amin (1989) views Eurocentrism as a culturalist phenomenon of irreducibly distinct cultural invariants that shape the 
historical paths of different peoples. Eurocentrism is therefore antiuniversalist, since it is not interested in seeking possible general laws of human evolution. But it does present itself as universalist, for it claims that imitation of the Western model by all people is the only solution to the challenges of our time. Although present in all areas, the Eurocentric basis of looking at the world is particularly manifest in the fields of language and literature. According to Mazrui and Mazrui (1998:1), this state of affairs has evolved as a result of two interrelated factors: originally, the failure of African societies to be expansionist enough in territorial terms and later, the failure of African people to be nationalistic enough in linguistic terms.

Ali Mazrui (1998:43-46) distinguishes at least five strands of linguistic Eurocentrism. The first is classificational Eurocentrism, whereby European linguists divided world languages along racial lines. This resulted into the unscientific assumption that the languages of the 'lower' races were somehow more primitive than the languages of the 'higher' races. African indigenous languages belonged to the former category while European ones were in the latter.

Secondly, Mazrui identified terminological Eurocentrism where all language families have been named by Europeans on the bases of criteria determined by Europeans. Consequently, the terminology of language classification has continued to be overwhelmingly Eurocentric. At the start of the twenty-first century, no clear and consensual picture exists with respect to either the number of languages on the African continent, or how these languages can be usefully classified. This has led to one of the most persistent myths in the study of African society: Linguistic Tower of Babel. It argues that linguistic diversity is of such proportions that Africans cannot share or work in their own languages (Prah 2002:12).

The third sense of linguistic Eurocentrism is semantic. This refers, in particular, to the tendency of European languages to use terms like 'animism', 'tribe', and 'primitive' in describing the African world, and to associate negative images with the terms. Mazrui has argued that because of the origins of English, as a language of whiteskinned people, it has accumulated a heritage of imagery that had invested black people with negative connotations.

Linguistic Eurocentrism has also been identified to be orthographic. European missionaries and scholars undertook a 
monumental task when they started transcribing African languages. It was the Latin script that came to serve as the foundation of this exercise. Latinization of African languages by missionaries was done with gusto even to languages like Hausa and Kiswahili which were closely related to Arabic script. Orthographic Arabicization of African languages was never entertained by European missionaries who equated the process to Islamization, and thus subjugation to Islamic faith.

Finally, Mazrui identifies the demographic sense of linguistic Eurocentrism. This refers to European linguistic expansionism and linguistic domination of peoples of other nations and nationalities, increasingly resulting in the capitulation of the world to European languages as first or additional media. Within the global arena, European languages are suffocating and marginalizing other languages with the probable result of linguicide.

The idea of language imposition as a strategy of power and political control in Africa must be kept in mind as a crucial political and social question. Language is merely a symbolic embodiment of the values, institutions, ideologies, and attitudes of a people. PanAfricanist linguistic discourse, therefore, emerged largely against this backdrop of African self-review and self-recognition. It served as an intellectual and cultural attempt to affirm an Africa affinity with Africa as well as to express faith in African languages.

African linguistic revivalism was therefore a combative weapon that had to be used against occupation by foreigners. Language was also meant to operate as an instrument for the re-assertion of African values, African history, and a whole ideology justifying the existence of the African world against 'their world'. Language revivalists wanted to re-establish the validity of their own languages and cultures. Theirs was a primarily political movement with a powerful cultural adjunct. Africans' self-emancipation was both physical and psychological. It was a realization that one cannot entirely, or even significantly, free the body from its chains unless one first frees the mind of its enslavement. According to Levy (1979:32-33), there is no politics that is not first of all linguistics. We know that the regulation of language is the best preparation for the regulation of souls.

European languages have been projected and privileged as the idioms of power, politics, religion, virtue, beauty, truth, and law and 
order. All African indigenous languages were dismissed as being incapable of carrying the burden of civilization. This was meant to make Africans feel insecure in their language, thus abandon their linguistic identity and take on the dominant European languages. And it is this reasoning that African linguistic nationalists wrestled with. They argued that language is the product of its unique history and culture and as a collective solidarity endowed with unique attributes. In short, African linguistic nationalism was concerned with the distinctiveness of African linguistic communities as the essence of African culture and African nation.

Language occupies an important place in the idea of a nation. Those who share a common understanding of lingusitic meanings may be said to constitute a nation. Bernard (1969) believes that:

By means of language, man is able to enter into communion with the way of thinking and feeling of his progenitors, to take part as it were, in the workings of the ancestral mind. He, in turn, again by means of language, perpetuates and enriches the thoughts, feelings and prejudices of past generations for the benefit of posterity. In this way, language embodies the living manifestation of historical continuity and the psychological matrix which man's awareness of his distinctive social heritage is aroused and deepened.

Pan-Africanist intellectuals can justifiably be regarded as heroes of African languages. Their role has been part of a process that addresses itself not only to the language issue as an instrument of cultural revolt and national reassertion, but also a way of re-establishing African values and traditions. Indeed, one of the elements unifying language intellectuals and other Pan-Africanist intellectuals is the focus on Africa as a central problematic in Eurocentric epistemology.

Pan-African intellectual nationalists stressed the achievements of their ancestral languages, and declared the importance of Africans studying them. They discussed the greatness and the uniqueness of African linguistic civilisation. They emphasized the unique creativity of African languages: the languages were the mother of philosophy, science, art and literature, and were responsible for the high standards of spiritual, moral and ethical life of Africans. Language as the epicentre of culture is the unique and original foundation upon which African civilization was built and upon which it survived through the centuries. Pan-Africanist intellectuals 
argued that Africans had their own distinct languages long before European languages became dominant. The revival of indigenous languages was encouraged because it was thought that the study of the languages, the most enduring monuments of the past greatness of the continent, would assist Africans in preserving their Africanity.

That language has been marginal to the self-identity of Africans, and indeed to the very need for a Pan-African language to write and symbolize the "African nation", is often denied or downplayed by African politicians and theorists. To say that Africa is a multinational continent is not to deny that the citizens view themselves for some purposes as a single people. According to Mudimbe (1988:47), during the history of African slavery and colonialism, the imposed languages of the enslaver and colonizer did a great deal to misrepresent human experience and contributed to the situation that lies behind our present crisis of consciousness. Until we forthrightly address the issues involved, until we formulate and execute bold, intelligent strategies for the creation of an effective language plan-ofaction, our otherwise excellent blueprints for material development will largely remain at the talking stage.

Africans can have a strong sense of common loyalty, despite their culturo-linguistic divisions. Africa's survival and emergence as a strong global player will largely depend on their allegiance to a larger political unit. This common loyalty may take, among other forms, that of a linguistic identity. Africans ought to be as patriotic as they wish to pay their allegiance to individual states, but they can simultaneously cultivate a sense of continental membership through linguistic identity. There is no likelihood that any of the European languages will become the languages of the masses in Africa, or of any very considerable portion of the population. Nevertheless, their statuses as literary languages of the educated are not without their import. For one thing, they keep these classes in touch with European public opinion.

The Pan-African opinion and efforts to address the language issue are best exemplified by the Inter-Governmental Conference on Cultural Policies in Africa (1975), and the Conference of Ministers of Education of African Member States (1976), both of which recommended the increased use of African languages. Despite the OAU Language Plan of Action for Africa (1986) setting the agenda 
and putting forth justification for the same, the issue of language rights in Africa still suffers from, among other problems, avoidance, vagueness, arbitrariness, fluctuation and declaration without implementation. Even if states and international organizations devote substantial human and financial resources to the sector, without doubt African leaders have not yet become sufficiently conscious of what is fundamentally at issue in the promotion of African languages and the importance of these in general development of the country (Phillipson, 1996:102).

This general apathy towards African languages has, perhaps, its genesis in a problem that Ki-Zerbo (1986:105) explains thus:

Even today our Ministers of Culture, with very few exceptions, are finding it hard to demonstrate the fact that African culture is not the artificial flower which adorns our hat, but the very blood which flows through our veins... Our Ministers of Economy go on harping on the imperative need for growth and 'modernisation'... Our Heads of State often consider culture as that additional element that is added to the budget when the latter is more or less well balanced.

Thus far, the ideas of a Pan-African language have been vague and conflicting. Africa does not yet possess that definite common language which captures and constitutes the psychological unity of her people. As the perception of a certain unity of African renaissance and development becomes clearer, and as the historic sense is strengthened through the rise of a strong political entity, we may look for powerful conscious efforts to realise an African unity of language and identity.

With regional integration becoming the norm on the continent, and informed by the globalization discourse, the rights, duties and powers of states are being re-articulated in a much more complex way, involving the development of a world of multiplayer power, multilayered authority and complex forms of governance. Forms of governance are being diffused below the level of the nation-state to sub-national regions, and above the level of the nation-state to supranational regions and global institutions. A shift is taking place from states as simple 'containers of political power' to states as just one layer, albeit an important layer, in a complex political process in which state sovereignty is a 'bargaining chip' for use in negotiations over extensive transnational phenomena. 
At independence, most African countries rigorously sought to define what their national cultures were. They did not leave it to chance. They promulgated it through schools, the media, national celebration and so on. And if you read through Pan-Africanist literature over the years, it is clear that national culture is not something that is taken for granted in the development project in Africa. There are constant reminders of 'our languages'; reminders that seem to suggest that national cultures and national languages are much more than appendages in the struggle for total liberation of Africa.

The African Union has pledged respect for the cultural and linguistic diversity of its Member States and has recognized minority languages as an inherent constituent in this regard. Thus, minority language groups should turn to the Union in response to grapple with minority language issues when perhaps domestic response to their concerns is either not forthcoming or simply not enough. This paper submits, however, that while there is a justifiable role for $\mathrm{AU}$ involvement in minority language issues, this competence is necessarily limited by the function and capacity of the AU more generally.

The recognition and realization of minority language rights are rooted in considerations of equality and non-discrimination, effective participation and cultural democracy. This holds true at both the national and international levels and applies equally to the AU as a governing entity that should create both rights and duties for those subject to its jurisdiction. Although without its official language policy more generally, it is fair to say that there exists something of an 'unofficial' AU language policy.

The work of the AU on language matters should be both consolidated and developed. However, the extent to which the AU can influence language rights protection within its Member States is a more problematic concept. Ambitions towards this end must be tempered by an appreciation and understanding of the capacity of the Union to act, and of the purpose and functions of the AU more generally-at least for now. How the AU might yet evolve may call for a reassessment of this type of competence. However, in the interim, we can only speculate in the realm of linguistic aspiration.

History seems to point to Kiswahili as the coming language of Africa; if indeed, a common African indigenous language is finally 
to be adopted. This language is among the most lavishly endowed in existence. Kiswahili is an idiom based upon Bantu speech, the populous tongues of Africa, an African language that originated from disparate dialects at the Coast of East Africa many centuries ago, to which has been added the wealth of Persian, Hindi, English, and Arabic diction. Throughout its existence, Kiswahili has witnessed momentous historical events that have transformed the language and its speakers into a global tongue that it is now. The language extends northward into southern Somalia, southward to northern Mozambique, eastward to major Indian Ocean Islands of Pemba, Zanzibar, the Comoros, and the northern tip of Madagascar, and westward into Uganda, Rwanda, Burundi and eastern Democratic Republic of the Congo. It is believed that Kiswahili, also spoken in some urban parts of Malawi, Zambia, Southern Sudan and Ethiopia, and with a growing number of speakers in the African Diaspora, is the most widespread indigenous language on the continent. Kiswahili is also taught in a large number of universities across the world. It is estimated that Kiswahili speakers number about one hundred- plus million people (Simala 2003).

The theories and activities of African revolutionaries like Julius Nyerere, Amilcar Cabral, Agostino Neto, Nelson Mandela and Eduardo Mondlane heavily influenced African American activists (Walters 1993). The 1970 Congress of African Peoples was an expression of this Pan African sensibility in the Diaspora and aimed at redefining Black Identity. The theme of the congress was 'Unity Without Uniformity' bringing together activists and legislators of disparate ideological orientations. An "ideological statement" adopted by the delegates on 6 September asserted that 'All black people are Africans, and that as Africans, we are bound together Racially, Historically, Culturally, Politically and Emotionally'. The statement focused on the need to develop a programme to ensure unified action in the Pan-African world. Julius Nyerere's ideas about Ujamaa (African socialism) and Pan-Africanism had radical influence on African American activists. Scores of African American activists traveled to Tanzania where they found a highly politicized nation that hosted several Pan-African liberation movements, opponents of neo-colonial African regimes and African Americans. They also saw for the first time, the power of an African language, 
Kiswahili, to unite disparate linguistic communities to fight for a just cause.

Consequently, in the Diaspora, Kiswahili has been adopted as the language of ritual and Pan African solidarity. Since the 1970s, Kiswahili has been used in Kwanzaa (a derivative from 'matunda ya kwanza', meaning first fruits), an African American harvest celebration designed to reconnect Diaspora blacks with their African roots. Kwanzaa is observed by over 28 million people of African descent in the United States (Karenga, 2000). According to Karenga, Kiswahili was chosen as the language of Kwanzaa in 1965 because it was 'non-ethnic' and 'non-tribal' language and 'Pan-African in character' (Karenga 1997:123). Karenga argues that Kiswahili is the most appropriate African language for African Americans because it reflects the syncretic nature of African Americans who claim all of Africa rather than one people or place. This borderless claim of Africanity is, as Karenga puts it, a 'matter of self-determination'. It is this agency that links the adoption of Kiswahili in the Diaspora to the diffusion of Kiswahili on the continent. The activists chose Kiswahili in an attempt to 'create, recreate and circulate African culture as an aid to building community, enriching black consciousness, and reaffirming the value of cultural grounding for life and struggle' (Karenga 1997:1).

For a long time, the OAU, did not interfere with the linguistic market place; it neither promoted nor inhibited the growth of any particular language. Rather, it responded with 'benign neglect' to linguistic differences. By deciding to accord Kiswahili official status, the AU provides what is probably the most important form of support needed to Pan-Africanize the language, since it guarantees the elevation of status of the language across the continent and beyond. However, giving recognition or support to Kiswahili is seen by some as unnecessary and unfair. It is unnecessary because a valuable language like Kiswahili will have no difficulty attracting users across the African continent. And it is unfair because it subsidizes a regional language at the expense of others.

It is worthy realising that not all language interests can be satisfied in a continent of conflicting linguistic interests and scarce resources. But we should not lose sight of the fact that promoting one regional language has costs for other regional languages and 
their speakers, and we need to determine when these trade-offs are justified. However, a system of universal individual rights already accommodates cultural differences, by allowing each person the freedom of speech. This enables people from different Ethnolinguistic backgrounds to pursue their distinctive languages without interference. Culture will remain a purely private affair in Africa. For while Kiswahili has official AU backing as the 'utilitarian' language of the Pan-African spirit, all indigenous African languages will compete on equal terms for cultural allegiance. It is the task of individual members of language communities to show the excellence of their languages on the linguistic market place.

As I have argued elsewhere (Simala 2001), African governments have not come to terms with the need for substantial indigenous languages development programme. Glorious declarations and resounding resolutions have had little effect. There is uncertainty and hesitation by governments regarding how much effort indigenous language rights deserve and require. But considering the fact that language is an essential precondition for economic and social development, for political participation and democracy, then the people and governments of Africa have not only a legitimate right to be concerned about indigenous languages, but also a duty to advance their cause, not merely with rhetoric, but more importantly with resources. As aptly observed by the OAU and Economic Commission for Africa representatives at the African Leadership Forum in Kampala in May 1991, almost everything that could be suggested by way of solution had been suggested and incorporated in some declarations or resolutions somewhere; a point had been reached where the multiplicity of purported solutions was adding to the problem.

\section{Conclusion}

This paper has been engaged in a discussion about language in the Pan-Africanist ideology. It has been argued that the discourse on Africa and Africanness was one of the first truly serious attempts to use the idea of Africa to develop a new discursive system in the so-called New World. What is clearly evident is the fact that Pan- 
Africanism led to the dialectical relationship between ideology, culture and race. Central to the discourse on Pan-Africanism are several crucial ideas, which include colonial oppression, racial differentiation, social imbalance, and a recurring European 'othering' of Africa. These factors working together were enough to generate a black discourse, not perfect, not unique, but distinct, so distinct that it can be intelligently analyzed.

The intellectual debate in Africa has been guided by grand social theories and inspired by epochal visions of social emancipation of all Africans. All African experiences, different as they may be as a result of the diversity of social and economic conditions, traditions and political, social and ideological beliefs, share a broad and common ground, namely that of the struggle against imperialism in all its forms and manifestations, for liberty, justice, peace, progress and prosperity. Pan-Africanism has helped deepen knowledge of these issues. And at the same time, it has given them a deeper and broader significance. It has dictated to African intellectuals the necessity of being committed to their continent and society. Indeed, as enlightened members of society, African intellectuals have gone further beyond commitment and taken leadership positions among their people, by actively participating in the process of individual and societal transformation.

It is quite noteworthy that the awakening of African nationalism was accompanied by a development of African Linguistic Nationalism. The desire for a Pan-African language, for a positive linguistic identity, while still incomplete and halting in implementation, is yet alive with new ideals. Linguistic Pan-Africanism does not mean hate for European languages. On the contrary. However, the appreciation of other languages cannot be fruitful or worthy except in so far as it can help enrich African languages, culture and civilization, by increasing awareness and broadening the African character.

African intellectuals should raise the banner of the great PanAfricanism spirit. They should undertake the task with the fortitude of fighters, the alertness of thinkers, the sensitivity of writers, and the firm resistance for which vanguards of intellectuals everywhere have been known. It is a responsibility necessitated in this crucial stage of history by the serious challenges facing the continent of Africa. The true African intellectuals, with their talent, ability and sensitivity, 
ought to respond to and to react to events around them, to the views, sentiments, emotions, pains and joys of the African people.

\section{Bibliography}

Ajala, A., 1973, Pan-Africanism: Evolution, Progress and Prospects, London; A. Deutsch

Alexander, N., ed., 1999, Language and Development in Africa: Social Dynamics, University of Cape Town: Centre for African Studies.

Amin, S., 1989, Eurocentrism, New York: Monthly Review Press.

Amin, S., 1994, Re-reading the Post-War Period: An intellectual Itinerary, New York: Monthly Review Press.

Anyidoho, K., 1992, 'Language and Development Strategy in Pan-African

Literary Experience', Research in African Literatures Vol. 23 No. 1, pp. 44-61.

Asmara Declaration on African Languages and Literatures, 2000, Conference on 'Against all Odds: African Languages and Literatures into the 21st Century', 11-17 January.

Balde, A, 1986, 'Black Civilization and Language', in The Arts and Civilization of Black and African Peoples, Centre for Black and African Arts and Civilization: Lagos.

Bamgbose, A., 1991, Language and the Nation: The Language Question in Sub-Saharan Africa, Edinburg: Edinburg University Press.

Banerjea, 1880, in E. Kedourie, ed., Nationalism in Asia and Africa, London: Weidenfeld \& Nicolson.

Boahen, A. A., ed., 1985, UNESCO General History, Vol.VII: Africa under

Foreign Domination, 1880-1935, London: Heinemann Educational Books.

Breuilly, J., 1982, Nationalism and the State, Manchester: Manchester University Press.

Chabal, P., 1981, 'The Social and Political Thought of Amilcar Cabral: A Reassessment', Journal of Modern African Studies, Vol. 19, pp. 13-56.

Conference of Ministers of Education of African Member States, 1976, Lagos.

Davidson, B., 1984, Africa in History, London: Paladin Books.

Diop, C. A., 1978, Black Africa: The Economic and Cultural Basis of a Federated State, Westport, C.T: Lawrence Hill. 
Fafunwa, B. A., 1989, 'Using National Languages in Education: A Challenge to African Educators', in African Thoughts on the Prospects of Education for All. Dakar: UNESCO.

Featherstone, M., ed., 1990, Global Culture: Nationalism, Globalization and Modernity, London: Sage Press.

Fishman,J. J., 1973, Language and Nationalism, Cambridge, Mass: Newbury House.

Gates, Jr., H. L., ed., 1986, “'Race’, Writing, and Difference”, Chicago: Chicago University Press.

Hans, K., 1955, Nationalism: Its Meaning and History, Princeton: NJD Van Nostrand.

Hayek, F.A, 1949, The Intellectuals and Socialism, Chicago: University of Chicago Press.

Herskovits, M. J., 1938, Acculturation: The Study of Culture Contact, New York: J.J. Augustin.

Hugh Trevor Roper, 1963. The Listener, 28 November.

Irele, A., ed., 1992, African Education and Identity, London: Hans Zell Publishers.

July, R.W., 1983, 'Toward Cultural Independence in Africa: Some Illustrations from Nigeria and Ghana', African Studies Review, Vol. 26. Nos.3\4.

Kashoki, M., 1984, The African Language as a Tool of Development, Kampala: BIL Papers No.1

Kinfe, A., 1991, Politics of Black Nationalism-From Harlem to Soweto, New Jersey: Africa World Press.

Ki-Zerbo, ed., 1981, UNESCO General History of Africa, vol.1 Methodology and African Prehistory, London: Heinemann Educational Books.

Ki-Zerbo, 1986, 'Cuture, Education and Development in Africa', FESTAC Collquium on Black Civilization and Education. Colloquium Proceedings Vol. 1 Lagos.

Kubayanda, J. B., 1990, The Poet's Africa-Africanness in the Poetry of Nicolas Guillen \& Aime Cesaire, New York: Greenwood Press.

Laitin, D.D., 1992, Language Repertoires and State Construction in Africa, New York: Cambridge University Press.

Levy, B., 1979, Barbarism with a Human Face, George Holoch, trans., New York: Harper \& Row.

Mazrui, A.A and A. M Mazrui, 1998, The Power of Babel, Oxford: James Currey. 
M'Bow, A., 1975, Intergovernmental Conference on Cultural Policies in Africa, Accra: UNESCO.

Mudimbe, V. Y., 1983, 'African Philosophy as an Ideological Practice: The Case of French-Speaking Africa' African Studies Review, Vol. 26. Nos.3\4.

Mudimbe, V.Y., 1988, The Invention of Africa. Bloomington: Indiana University Press.

Niane, D. T., ed., 1984, UNESCO General History of Africa, Vol.IV: Africa from the Twelfth to Sixteenth Century, London: Heinemann Educational Books.

Nicol, D.,1979, 'Alioune Diop and the African Renaissance', African Affairs, Vol. 78. No. 310, Oxford: Oxford University Press.

Nkrumah, K., 1964, Consciencism, London: Heineman.

OAU BIL Publication no.6 Linguistic Liberation and Unity of Africa, Kampala.

Olisanwuche, P., 1977, 'What is Pan-Africanism?', Journal of African Studies, Vol. 4 No. 2.

Olukoshi, A., 2002, 'Hope for a New Millennium', CODESRIA Bulletin, Nos. $3 \& 4$.

Okita, S. I., 1992, 'African Culture and the Search for Identity', in A. Irele, ed., African Education and Identity, London: Hans Zell Publishers.

Phillipson, T., 1996, Cultural Imperialism, Oxford: Oxford University Press.

Prah, K. K., 1993, Mother Tongue for Scientific and Technological Development in Africa, Bonn: Zentrulstelle fur Erziehung, Wissenschaft und Dokumentation.

Prah, K. K., 1996, African Languages for the Mass Education of Africans, Bonn: German Foundation for International Development.

Prah, K. K., 2002, 'Researching African Languages for Scientific and Technological Development: The CASAS Experience', in Speaking African: African Languages for Education and Development. F. R. Owino, ed., Cape Town: CASAS.

Shivji, I. G., 2003, 'The Life and Times of Babu: The Case of Liberation and Revolution', Review of African Political Economy, No. 95, pp. 109-118.

Simala, I.K., 1996, 'Religious Nationalism and the Language Question in Colonial Kenya: A Critical Perspective', in Kenya Journal of Education, Bureau of Educational Research, Kenyatta University Vol.6. No. 1, pp. 87-98. 
Simala, I. K., 1998, 'Ethnolinguistic Nationalism and Identity in Africa: Its Evolution and Implications to Nation-States', in B. A. Ogot, ed Ethnicity, Nationalism and Democracy in Africa, Maseno, IRPS.

Simala, I. K., 2001, 'African Linguistic Nationalism and the Discourse of Globalization', in Globalization, Democracy and Development in Africa: Challenges and Prospects, T. Assefa, S.M. Rugumamu \& A.G.M. Ahmed, eds., Addis Ababa: OSSREA.

Simala, I .K., 2002, 'Empowering Indigenous African Languages for Sustainable Development', in Speaking African: African Languages for Education and Development. F. R. Owino, ed., Cape Town: CASAS.

Simala, I .K., 2003 Linguistic Globalization, Regional Integration and the Place of Kiswahili in Eastern Africa. Paper Presented at the CODESRIA Regional Conference for East Africa, held at the Global Hotel, Addis Ababa on 30-31 October.

Smith, A.D., 1971, Theories of Nationalism, Duckworth: London.

Stonequist, E.V., 1937, The Marginal Man: A Study in Personality and Culture Conflict, New York: Russell \& Russell.

Thomson, V. B. and J. Hatch, 1967, Africa and Unity: The Evolution of Pan-Africanism, London.

Van Niekerk, B., 1970, The African Image(Negritude) in the Work of Leopold Sedar Senghor, Cape Town.

Wa Thiong'o, N., 1980, quoted in Lemuel A. Johnson, 'Cuba and AfroLatin Radicalism: Context and Literature in a Paradigm', Journal of Caribbean Studies, Vol. 1, Nos. 2-3.

Wodajo, K., 1964, 'Pan-Africanism:The Evolution of an Idea', Ethiopia, no.2.

Wodajo, K., 1993, Moving the Centre: The Struggle for Cultural Freedoms. London: James Currey.

Yoshino, K., 1992, Cultural Nationalism in Contemporary Japan, London: Routledge. 